\title{
Pengembangan Media Kartu Remi Pancasila "Rensla" untuk Meningkatkan Civic Literacy Siswa
}

\author{
Moh. Farizqo Irvan ${ }^{1 *}$, Feylosofia Putri Agry ${ }^{2}$, Habibullah $^{3}$ \\ ${ }^{1.2}$ Pendidikan Guru Sekolah Dasar, Universitas Negeri Semarang \\ ${ }^{3}$ Pendidikan Matematika, Universitas Negeri Yogyakarta \\ *Email korespondensi: farizqor08pgsd@gmail.com
}

\begin{abstract}
The development of the industrial revolution era 4.0 demands the production of quality human resources without neglecting individuals as good citizens. The purpose of this study is to develop and determine the effectiveness of Rensla card media in improving the civic literacy skills of elementary school students. This type of research is a research and development $(R \& D)$ type ADDIE. The population of this study is the second-grade students of SD Negeri Tambakaji 03 Semarang City, amounting to 64 students with a sample of 32 students who were determined through cluster random sampling technique. The data collection technique is done by interview, scale, questionnaire, and test. The feasibility data for Rensla cards were analyzed descriptively and the students' civic literacy abilities were analyzed using dependent t-tests. The results showed that Rensla cards media was considered very feasible by media and material experts with a feasibility score of 85 and 88. Also, Rensla cards media was effective in increasing student civic literacy as evidenced by the results of the dependent t-test with a p-value of $0.000<0.05$. Thus, it can be concluded that the Rensla cards media developed is suitable for use in improving the civic literacy of elementary school students.
\end{abstract}

Keywords: Bridge cards, Pancasila, Civic literacy, Elementery School Students.

\begin{abstract}
Abstrak
Perkembangan era revolusi indusri 4.0 menuntut dihasilkannya sumber daya manusia yang berkualitas tanpa mengesampingkan individu sebagai good citizen. Tujuan penelitian ini yaitu untuk mengembangkan dan mengetahui keefektifan media kartu remi Pancasila dalam meningkatkan kemampuan civic literacy siswa sekolah dasar. Jenis penelitian ini merupakan research and development $(\mathrm{R} \& \mathrm{D})$ tipe ADDIE. Populasi dari penelitian ini yaitu siswa kelas II SD Negeri Tambakaji 03 Kota Semarang yang berjumlah 64 siswa dengan sampel yaitu 32 siswa yang ditentukan melalui teknik cluster random sampling. Teknik pengumpulan data dilakukan dengan wawancara, skala, angket, dan tes. Data kelayakan media kartu remi pancasila dianalisis secara deskriptif dan kemampuan civic literacy siswa dianalisis menggunakan uji-t dependen. Hasil penelitian menunjukkan bahwa media Rensla dinilai sangat layak oleh ahli media dan materi dengan skor kelayakan sebesar 85 dan 88. Selain itu, media kartu Rensla juga efektif dalam meningkatkan civic literacy siswa yang dibuktikan melalui hasil uji-t dependen dengan p-value $0.000<$ 0.05. Dengan demikian, dapat disimpulkan bahwa media kartu Rensla yang dikembangkan layak untuk digunakan dalam meningkatkan civic literacy siswa sekolah dasar.
\end{abstract}

Kata Kunci: Kartu remi, Pancasila, Civic literacy, Siswa sekolah dasar. 


\section{A. Pendahuluan}

Pendidikan di era revolusi industri 4.0 memiliki tantangan untuk mempersiapkan sumber daya manusia yang berkualitas dan terampil, tanpa mengesampingkan karakter dan perannya sebagai warga negara yang baik (good citizehip). Altintaş \& Karaaslan (2019) menyebutkan bahwa tantangan tersebut menjadi prioritas yang perlu untuk dipenuhi di tengah semakin derasnya arus globalisasi. Pembentukan sumber daya manusia berkualitas yang sekaligus menjadi warga negara yang baik dapat dilakukan dengan memberikan pemahaman tentang pengetahuan dan keterampilan tentang kewarganegaraan. Pemahaman pengetahuan yang baik dan keterampilan yang mumpuni mendorong partisipasi sebagai warga negara yang baik meningkat (Rahman, 2016). Kondisi seperti itu dapat dikembangkan melalui peningkatan kemampuan civic literacy setiap individu.

Fudge \& Skipworth (2017) menyebutkan bahwa civic literacy merupakan keterampilan yang berharga bagi siswa untuk dipelajari karena memberikan landasan bagi pemahaman yang lebih baik tentang kompleksitas pemerintahan dan dunia politik. Terdapat tiga komponen inti dari civic literacy seperti pengetahuan kewarganegaraan (civic knowledge), keterampilan kewarganegaraan (civic skills), dan karakter atau sikap kewarganegaraan (civic dispositions) (Raharjo et al., 2017). Pemahaman yang baik tentang civic literacy dapat mempersiapkan siswa dalam memiliki pengetahuan, keterampilan, dan partisipasi menjadi warga negara yang demokratis (Morgan, 2016). Hylton (2018) menyebutkan bahwa civic literacy memiliki hubungan dengan ikatan kewarganegaraan siswa. Semakin siswa memiliki kemampuan civic literacy yang baik, maka siswa memiliki potensi menjadi warga Negara yang baik semakin besar. Hal tersebut dapat dimaknai bahwa pendidikan di sekolah -termasuk sekolah dasar- memiliki peran dalam meningkatkan kemampuan civic literacy.

Penumbuhan kemampuan civic literacy bagi siswa SD dapat dilakukan dengan mengenalkan siswa lebih mandalam tentang negaranya sejak dini. Pembelajaran Pendidikan Pancasila dan Kewarganegaraan (PPKn) di sekolah dasar merupakan salah satu sarana dalam menumbuhkan civic literacy bagi siswa. Tentunya pada jenjang pendidikan SD civic literacy tidak memiliki pengertian 
sekompleks itu. Civic literacy di SD lebih ditekankan pada pengenalan tentang dasar negara dan lebih ditekankan pada komponen civic knowledge (pengetahuan kewarganegaraan). Mengingat betapa pentingnya kemampun tersebut, maka penting bagi siswa untuk menguasai kemampuan civic literacy. Guru SD dituntut dapat memvisualisasikan konsep yang abstrak menjadi lebih konkret kepada siswanya. Proses visualisasi tersebut membutuhkan adanya media pembelajaran tentang sila-sila Pancasila dan penerapan dalam kehidupan sehari-hari untuk penyampaiannya.

Namun, berdasarkan fakta di lapangan diperoleh informasi bahwa penggunaan media pembelajaran di SD Negeri Tambakaji 03 masih terbatas. Pembelajaran didominasi menggunakan buku teks (buku guru dan buku siswa). Selain itu, media Powerpoint juga beberapa kali digunakan, namun belum dapat memfasilitasi siswa untuk belajar secara mandiri. Siswa masih terbolak-balik dalam menyebutkan contoh penerpan dari sila-sila Pancasila. Selain itu, pembelajaran juga masih bersifat satu arah, sehingga menyebabkan motivasi dan minat belajar siswa menjadi rendah.

Motivasi dan minat belajar yang rendah berpengaruh juga terhadap pemahaman dan hasil belajar siswa yang rendah (Phuntsho, 2018). Oleh karena itu, dibutuhkan media pembelajaran yang dapat memvisualisasikan bentukbentuk penerapan nilai-nilai Pancasila dalam kehidupan sehari-hari, meningkatkan kemampuan civic literacy, dan dapat mengakomodir kemandirian belajar siswa. Salah satu alternatif media pembelajaran yang dapat digunakan yaitu media pembelajaran kartu Remi Pancasila.

Media pembelajaran kartu Remi Pancasila "Rensla" merupakan pengembangan dari kartu remi yang biasa digunakan dalam permainan seharihari. Kartu remi tersebut kemudian didesain ulang dengan memasukkan lambang-lambang lima sila dalam Pancasila yang terdiri dari gambar bintang, rantai, pohon beringin, kepala banteng, dan padi kapas. Selain itu, media pembelajaran Rensla juga memuat gambar-gambar yang merupakan penerapan dari sila-sila Pancasila dalam kehidupan sehari-hari.

Saunders et al. (1996) menyebutkan bahwa simulasi dan permainan flash card merupakan bagian dari pendekatan pembelajaran aktif, sehingga dapat 
meningkatkan partisipasi siswa dalam pembelajaran. Unsur animasi dan gambar pada media pembelajaran dapat menciptakan pembelajaran yang mendukung peningkatan pemahaman siswa (Baglama et al., 2018). Lebih lanjut, Shabiralyani et al. (2015) menyebutkan bahwa proses visualisasi memiliki peran penting dalam pembelajaran karena memahamkan siswa sekolah dasar terhadap konsep yang abstrak menjad lebih konkret.

Penelitian tentang pengembangan media pembelajaran berupa permainan kartu seperti kartu Rensla yang memuat unsur gambar dan berbasis permaianan sudah pernah dilakukan dan efektif dalam meningkatkan hasil belajar, pemahaman, dan keterampilan membaca permulaan siswa. Namun, terdapat perbedaan bentuk pengembangan dan variabel yang diteliti apabila dibandingkan dengan pengembangan kartu Rensla yang digunakan untuk meningkatkan keterampilan civic literacy siswa seperti penelitian Mardati \& Wangid (2015) yang mengembangkan permainan kartu gambar dengan teknik make a match yang efektif meningkatkan hasil belajar siswa kelas I SD. Rumidjan et al. (2017) mengembangkan media kartu kata untuk melatih keterampilan membaca permulaan atau literasi dasar pada siswa kelas I SD. Penelitian selanjutnya yaitu tentang keefektifan media pembelajaran berupa permainan kartu dalam meningkatkan pemahaman siswa (Su et al., 2014).

Berdasarkan uraian di atas, maka terdapat kebutuhan pengembangan media pembelajaran untuk siswa kelas II sekolah dasar yang dapat meningkatkan kemampuan civic literacy siswa. Humaini (2018) menyebutkan bahwa penggunaan media pembelajaran berupa kartu berbasis permainan memberikan pengaruh positif terhadap proses pembelajaran dan hasil belajar siswa. Oleh karena itu, tujuan dari penelitian ini yaitu mengembangkan media pembelajaran kartu Remi Pancasila yang layak dan efektif dalam meningkatkan kemampuan civic literacy siswa kelas II sekolah dasar.

\section{B. Metode Penelitian}

Penelitian ini merupakan penelitian dan pengembangan (Research and Development) dengan desain pengembangan ADDIE yang terdiri dari lima tahapan. Kelima tahapan tersebut terdiri dari (1) analysis, (2) design, (3) 
developments, (4) implementation, and (5) evaluation. Pada tahap analysis dilakukan analisis kebutuhan pengembangan media Rensla kepada siswa sebagai acuan dalam mengembangkan media. Pada tahap design yang dilakukan meliputi penyusunan rancangan media. Tahap development, dilakukan pengembangan media. Pada tahap ini instrumen dan media yang dikembangkan divalidasi oleh dosen ahli. Pada tahap implementation, media yang dikembangkan diujicobakan kepada siswa apabila sudah dinyatakan valid oleh dosen ahli. Selanjutnya, untuk memperoleh data keefektifan media dilakukan evaluasi pembelajaran berupa pengerjaan tes. Tahap terakhir yaitu evaluation, pada tahap ini dilakukan untuk menilai media pembelajaran yang dikembangkan secara keseluruhan setelah diperbaiki sebelum nantinya didiseminasikan.

Subjek penelitian ini yaitu siswa kelas II SD Negeri Tambakaji 03 tahun ajaran 2017/2018. Jumlah populasi penelitian yaitu 64 siswa, dengan jumlah sampel 32 siswa (20 siswa perempuan dan 12 siswa laki-laki). Teknik penentuan sampel dilakukan dengan teknik cluter random sampling. Teknik pengumpulan data pada penelitian ini meliputi wawancara, angket, skala, dan tes. Instrumen yang digunakan pada penelitian ini dibagi menjadi dua, yaitu (1) instrumen untuk menilai kelayakan media yang dikembangkan (lembar penilaian ahli media dan materi) dan (2) instrumen soal pre-test dan post-test untuk mengukur keefektifan media yang dikembangkan terhadap kemampuan civic literacy siswa sekolah dasar.

Data penelitian dianalisis menggunakan teknik analisis kualitatif dan kuantitatif. Analisis kualitatif menggunakan analisis deskriptif untuk menyajikan data kelayakan media yang dikembangkan dikonversi dari data kuantitatif menjadi lima kategori kualitatif. Data kuantitatif yang berupa hasil evaluasi belajar dianalisis menggunakan analisis statistik uji-t dependen. Uji-t dapat dilakukan apabila sudah memenuhi uji prasyarat sebelumnya, yaitu uji normalitas dan uji homogenitas. 


\section{Hasil dan Pembahasan}

\section{Kelayakan Media Pembelajaran Remi Pancasila "Rensla"}

Media Remi Pancasila "Rensla" merupkan hasil pengembangan media kartu remi. Media Rensla berupa media pembelajaran dalam bentuk kartu yang memiliki unsur utama berupa gambar yang merupakan visualisasi dari bentuk pengamalan nilai-nilai Pancasila dalam kehidupan sehari-hari. Penggunaan media juga dikemas dalam bentuk permainan sehingga menarik perhatian dan memudahkan siswa dalam mempelajarinya. Tampilan media Rensla dapat dilihat pada Gambar 1 di bawah ini.
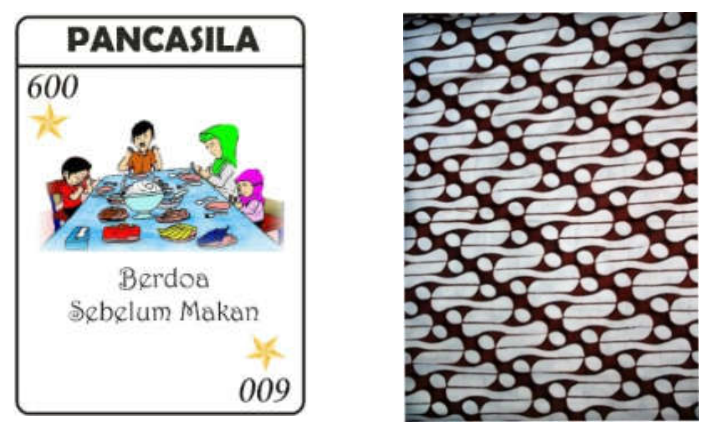

Gambar 1.

Tampilan Media Rensla Tampak Depan dan Belakang

Sebelum diujicobakan dalam pembelajaran, media Rensla perlu diujicoba terlebih dahulu kelayakannya. Kelayakan produk berupa media yang dikembangkan dinilai oleh ahli media dan ahli materi. Penilaian oleh ahli media yaitu terdiri dari lima aspek, yaitu: (1) konsistensi media, (2) format media, (3) organisasi media, (4) daya tarik media, dan (5) font pada media. Di bawah ini disajikan hasil penilaian ahli media terhadap media Rensla:

Tabel 1.

Hasil Penilaian Media Rensla oleh Ahli Media

\begin{tabular}{|c|l|c|c|}
\hline No & \multicolumn{1}{|c|}{ Aspek } & Skor & Kategori \\
\hline 1 & Konsistensi media & 8 & Layak \\
\hline 2 & Format media & 15 & Sangat Layak \\
\hline 3 & Organisasi media & 20 & Layak \\
\hline 4 & Daya tarik media & 30 & Sangat Layak \\
\hline 5 & Font media & 12 & Layak \\
\hline \multicolumn{2}{|c|}{ Total Skor } & $\mathbf{8 5}$ & Layak \\
\hline
\end{tabular}


Berdasarkan Tabel 1, diperoleh infromasi bahwa hasil penilaian oleh ahli media memperoleh skor total sebesar 85 dengan kategori layak. Batas minimal media Rensla dinyatakan memenuhi kriteria layak apabila melampaui skor 68. Hasil perbandingan penilaian oleh ahli media terhadap kriteria minimal kelayakan media Rensla dapat dilihat pada Gambar 2 di bawah ini.

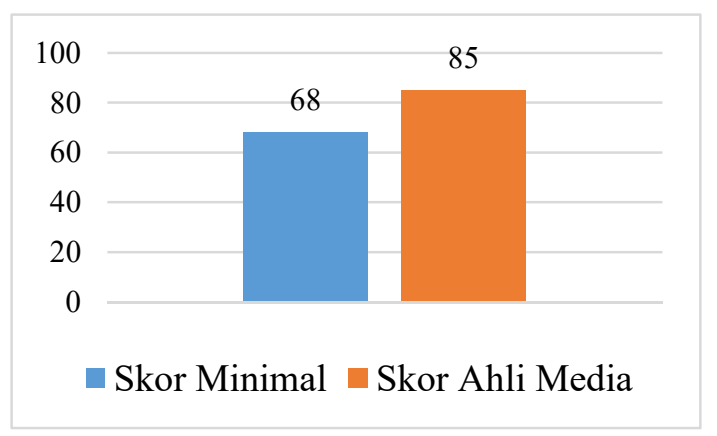

Gambar 2.

Hasil Penilaian Ahli Media terhadap Skor Minimal

Kelayakan media Rensla tidak hanya dinilai oleh ahli media, tapi juga oleh ahli materi. Penilaian kelayakan oleh ahli materi terdiri dari lima aspek yang meliputi, (1) kesahihan, (2) tingkat kepentingan, (3) learnability, (4) daya tarik, dan (5) kebermanfaatan media. Penilaian ahli materi memiliki kriteria kelayakan minimal yang harus dipenuhi agar media yang dikembangkan dapat diujicobakan sama seperti ahli media. Berikut ini disajikan hasil penilaian ahli materi terhadap media Rensla pada Tabel 2.

Tabel 2.

Hasil Penilaian Media Rensla oleh Ahli Materi

\begin{tabular}{|c|l|c|c|}
\hline No & \multicolumn{1}{|c|}{ Aspek } & Skor & Kategori \\
\hline 1 & Kesahihan media & 22 & Sangat Layak \\
\hline 2 & Tingkat kepentingan & 15 & Layak \\
\hline 3 & Learnability & 27 & Sangat Layak \\
\hline 4 & Daya tarik & 15 & Sangat Layak \\
\hline 5 & Kebermanfaatan & 9 & Sangat Layak \\
\hline \multicolumn{2}{|c|}{ Total Skor } & $\mathbf{8 8}$ & Sangat Layak \\
\hline
\end{tabular}

Berdasarkan Tabel 2, dapat dilihat bahwa hasil penialain oleh ahli materi terhadap media Rensla yaitu sebesar 88 dengan kategori sangat layak. Batas minimal media dinyatakan layak oleh ahli materi apabila hasil penilaian mencapai minimal skor 68. Dengan demikian, dapat disimpulkan 
bahwa media Rensla dinyatakan layak secara materi. Hasil perbandingan penilaian oleh ahli media terhadap kriteria minimal kelayakan media Rensla dapat dilihat pada Gambar 3 berikut ini.

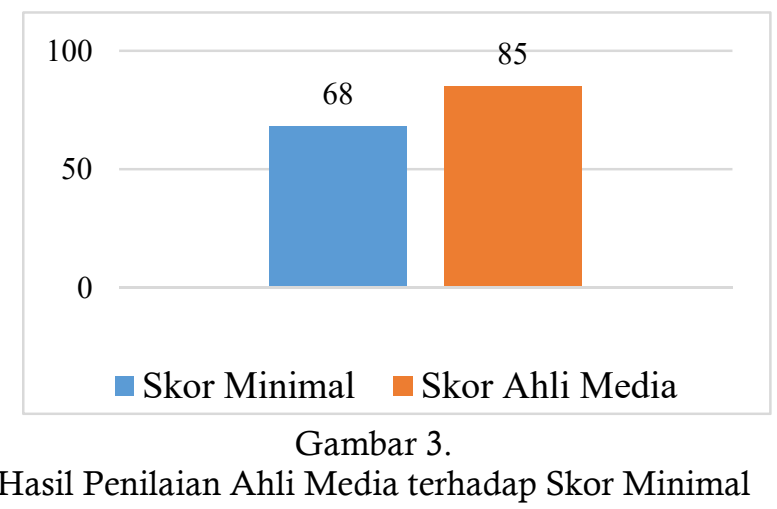

Respon guru dan siswa terhadap media Rensla juga menunjukkan hasil yang positif. Data hasil respon guru menunjukkan bahwa skor yang diberikan oleh guru yaitu sebesar 89 (kategori sangat baik) dari kriteria minimal yaitu 61, 3. Untuk hasil respon siswa memperoleh skor sebesar 13, 54 (kategori sangat baik) dari kriteria minimal yaitu 9, 1. Di bawah ini disajikan hasil perbandingan respon guru dan siswa terhadap kriteria minimal kelayakan media Rensla pada Gambar 4.
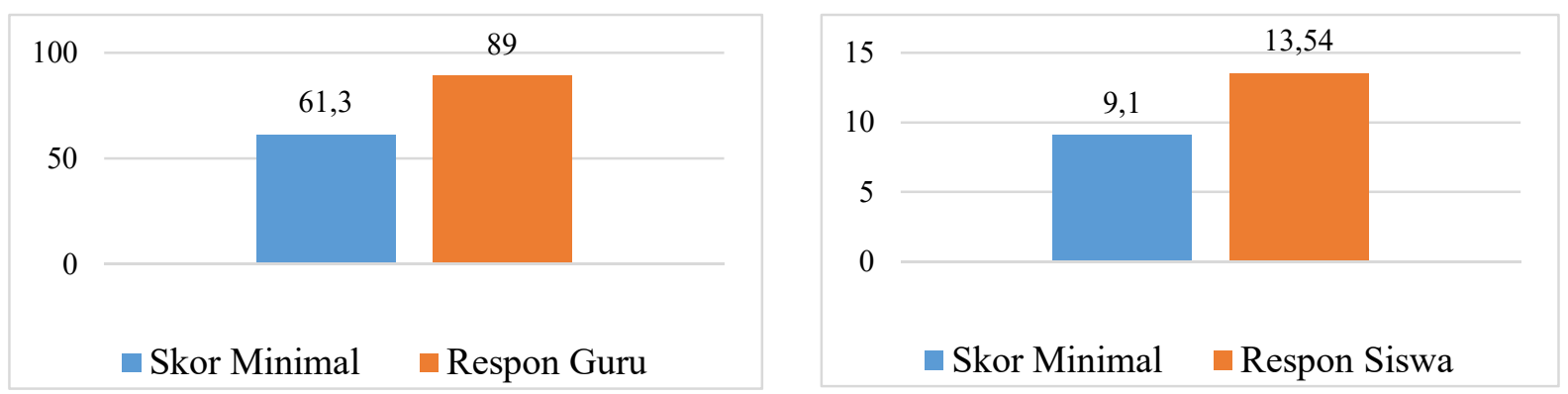

Gambar 4.

Hasil Respon Guru dan Siswa terhadap Skor Minimal.

\section{Efektivitas Media Remi Pancasila dalam Meningkatkan Civic Literacy}

Setelah dinyatakan layak oleh ahli media dan materi serta memperoleh respon positif dari guru dan siswa, media Rensla kemudian diiujicobakan kepada siswa kelas II sekolah dasar. Hal ini dilakukan untuk mengetahui keefektifan media Rensla yang dikembangkan. Keefektifan media Rensla diperoleh dari rata-rata hasil tes kemampuan civic literacy siswa sebelum dan 
setelah menggunakan media yang dikembangkan. Rata-rata hasil kemampuan civic literacy tersebut diuji dengan menggunakan uji-t dependen yang sebelumnya telah diujii normalitas dan homogenitas datanya. Di bawah ini disajikan data rata-rata kemampuan civic literacy siswa kelas II SD sebelum dan sesudah menggunakan media Rensla pada Gambar 5.

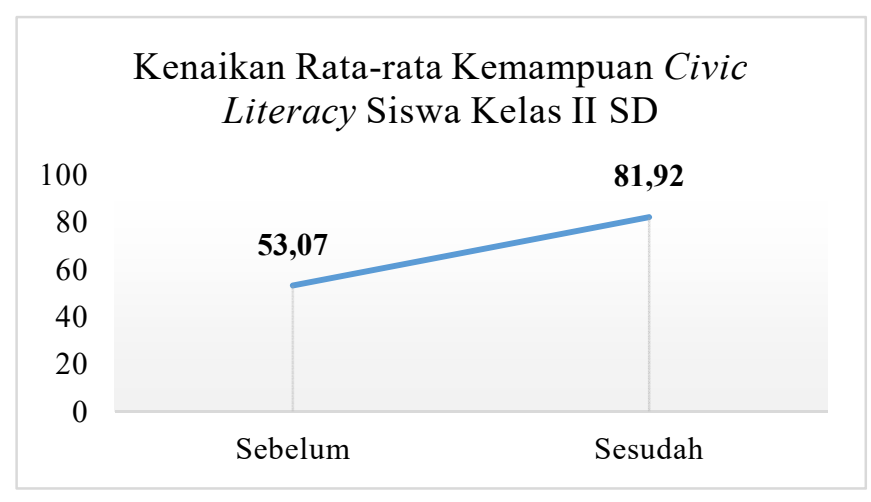

Gambar 5.

Kenaikan Rata-rata Kemampuan Civic Literacy Siswa

Berdasarkan Gambar 5 di atas, diperoleh informasi bahwa terdapat peningkatan kemampuan civic literacy siswa kelas II SD. Kemampuan civic literacy sesudah menggunakan media Rensla dalam pembelajaran mengalami peningkatan rata-rata sebesar 28,85 dari skor sebelum menggunakan media Rensla. Nilai n-gain yang diperoleh yaitu sebesar 0,61 dan masuk kategori peningkatan yang sedang. Signifikansi peningkatan kemampuan civic literacy diperoleh dengan melakukan uji-t dependen. Uji-t dependen dilakukan untuk mengetahui apakah terdapat perbedaan yang signifikan antara kemampuan civic literacy siswa sebelum dan sesudah menggunakan media Rensla dalam pembelajaran. Di bawah ini disajikan hasil uji-t dependen kemampuan civic literacy siswa kelas II sekolah dasar pada Tabel 4.

Tabel 4.

Hasil Uji-t Dependen Kemampuan Civic Literacy Siswa Kelas II SD

\begin{tabular}{|c|c|c|c|}
\hline Data yang Diuji & Sig. (2-tailed) & Hipotesis & Keterangan \\
\hline $\begin{array}{c}\text { Kemampuan civic literacy siswa } \\
\text { kelas II SD sebelum dan } \\
\text { setelah menggunakan media }\end{array}$ & 0,000 & $(0,000<0,05)$ & $\begin{array}{c}\text { Terdapat } \\
\text { Perbedaan yang } \\
\text { Signifikan }\end{array}$ \\
\hline
\end{tabular}


Berdasarkan data yang tersaji pada Tabel 4, diperoleh informasi bahwa hasil uji-t dependen kemampuan civic literacy siswa memiliki nilai signifikansi lebih kecil dari 0,05 $(0,000<0,05)$, dengan demikian dapat dimaknai bahwa terdapat perbedaan yang signifikan antara kemampuan civic literacy siswa sebelum dan sesudah menggunakan media Rensla. Berdasarkan informasi di atas, maka dapat disimpulkan bahwa pengembangan media Rensla merupakan media yang layak dan efektif dalam meningkatkan kemampuan civic literacy siswa kelas II sekolah dasar.

Pengembangan media Rensla memperhatikan beberapa prinsip pengembangan media pembelajaran sehingga efektif dimanfaatkan dalam pembelajaran. Abidin (2016) menyebutkan bahwa terdapat enam prinsip dalam pemilihan dan pengembangan media yang meliputi, (1) tujuan pembelajaran, (2) karakteristik siswa, (3) jenis rangangan yang diinginkan, (4) keadaan lingkungan, (5) kondisi setempat, dan (6) luasnya sasaran. Keenam kriteria tersebut saling berhubungan antara satu dengan yang lain, sehingga dapat menghasilkan media Rensla yang layak dan efektif dalam meningkatkan kemampuan civic literacy siswa sekolah dasar.

Peningkatan kemampuan civic literacy siswa dipengaruhi oleh unsur yang terdapat pada media Rensla. Media Rensla memiliki unsur visual yang berupa gambar atau ilustrasi dari contoh pengamalan nilai-nilai Pancasila dalam kehidupan sehari-hari. Shabiralyani et al. (2015) menyebutkan bahwa unsur visual pada media pembelajaran memberikan pengaruh terhadap proses pembelajaran. Media yang memuat unsur gambar atau ilustrasi dapat menarik perhatian dan meningkatkan motivasi belajar siswa (Verhallen \& Bus, 2011). Selain dapat meningkatkan motivasi dan menarik perhatian, media pembelajaran yang memuat unsur gambar juga dapat meningkatkan pemahaman siswa terhadap materi pembelajaran yang bersifat abstrak (Aukerman \& Chambers Schuldt, 2016). Kasmaienezhadfard et al. (2015) dan Yang et al. (2016) menyebutkan bahwa gambar memiliki peran yang penting dalam pembelajaran karena menjadi sarana memahami sesuatu yang abstrak menjadi lebih kongkret sesuai dengan karakteristik siswa sekolah dasar yang berada pada masa operasional konkret (Izzaty et al., 2013). 
Selain unsur visual pada media Rensla, alasan lain yang menjadikan media ini efektif digunakan dalam pembelajaran yaitu penggunaan media Rensla yang dikemas ke dalam permainan. Mostowfi et al. (2016) menyebutkan bahwa media pembelajaran berbasis permaianan sangat mendukung proses pembelajaran. Pada media Rensla siswa diminta untuk memasangkan simbol sila-sila Pancasila dengan bentuk pengamalan nilainilai Pancasila dalam kehidupan sehari-hari.

Hal ini sejalan dengan pendapat Gabriel et al. (2012) yang menyebutkan bahwa pemahaman siswa sekolah dasar dapat dibentuk melalui aktivitas mengingat, membandingkan, dan memasangkan kartukartu dalam permainan. Mengkolaborasikan pembelajaran dengan permaian kartu Rensla dapat menciptakan pembelajaran yang menyenangkan. Pembelajaran menggunakan permainan kartu dapat meningkatkan pengetahuan siswa (Liu \& Chen, 2013; Scalise et al., 2020).

Hassan et al. (2018) menyebutkan bahwa permainan kartu berhubungan erat dengan minat dan antusias dalam pembelajaran yang aktif. Minat dan antusias yang tinggi dalam pembelajaran dapat mendorong siswa untuk aktif berpartisipasi dalam pembelajaran (Sahrin \& Hasan, 2019; Selvi \& Çoşan, 2018). Selain dapat meningkatkan partisipasi dalam pembelajaran, menurut Padang et al. (2018) pembelajaran menggunakan media permainan kartu dapat meningkatkan hasil belajar siswa sekolah dasar.

\section{Kesimpulan}

Berdasarkan uraian yang telah dipaparkan sebelumnya pada hasil dan pembahasan, dapat ditarik simpulan bahwa media Remi Pancasila "Rensla" yang dikembangkan sudah memenuhi kriteria kelayakan berdasarkan hasil penilaian ahli media dan ahli materi yaitu sebesar 85 dengan kategori layak dan 88 dengan kategori sangat layak. Selain itu, media Rensla juga efektif dalam meningkatkan civic literacy siswa sekolah dasar. Hal tersebut dibuktikan dengan adanya perbedaan yang signifikan dari kemampuan civic literacy siswa awal yaitu 53.07 dan akhir yaitu 81,92. Peningkatan kemampuan civic literacy memperoleh skor n-gain 0,61 dengan kategori sedang. Uji-t yang dilakukan juga 
menunjukkan perbedaan kemampuan civic literacy siswa yang signifikan $(0,000<$ 0,05). Perbedaan tersebut dikarenakan siswa merasa lebih termotivasi dan lebih mudah dalam memahami pembelajaran.

Dengan demikian, media Rensla yang telah dikembangkan dapat digunakan oleh guru dalam meningkatkan kemampuan civic literacy siswa sekolah dasar. Selain itu, untuk penelitian selanjutnya dapat dilanjutkan untuk mengetahui pengaruh media Rensla tidak hanya pada ranah kognitif saja (civic literacy), melainkan terhadap ranah afektif dan psikomotorik siswa sekolah dasar.

\section{Daftar Pustaka}

Abidin, Z. (2016). Penerapan pemilihan media pembelajaran. Edcomtech, 1(1), 9-20.

Altintaş, I. N., \& Karaaslan, H. (2019). Study on effective citizenship education and its dimensions. Universal Journal of Educational Research, 7(7), 1567-1579. https://doi.org/10.13189/ujer.2019.070711

Aukerman, M., \& Chambers Schuldt, L. (2016). "The Pictures Can Say More Things": Change Across Time in Young Children's References to Images and Words During Text Discussion. Reading Research Quarterly, 51(3), 267-287. https://doi.org/10.1002/rrq.138

Baglama, B., Yucesoy, Y., \& Yikmis, A. (2018). Using animation as a means of enhancing learning of individuals with special needs. TEM Journal, 7(3), 670677. https://doi.org/10.18421/TEM73-26

Fudge, D., \& Skipworth, S. A. (2017). Kids in the capitol: improving civic literacy through experiential learning. Learning: Research and Practice, 3(2), 163-167. https://doi.org/10.1080/23735082.2017.1349169

Gabriel, F., Coché, F., Szucs, D., Carette, V., Rey, B., \& Content, A. (2012). Developing children's understanding of fractions: An intervention study. Mind, Brain, and Education, 6(3), 137-146. https://doi.org/10.1111/j.1751228X.2012.01149.X

Hassan, N. F. H. N., Jaafar, N. F. H. N., Ahmad, N., Ibrahim, N., \& Chek, W. A. $\mathrm{K}$. W. (2018). The role of games card in active teaching and learning approach: a case study of enterpreneurial creative card (ec-card). Journal of Fundamental and Applied Sciences, 10(4S), 829-842. https://doi.org/10.4314/jfas.v10i4s.248

Humaini, A. (2018). Experimental research: the effectiveness of card game learning media in learning shorof. Jurnal Al Bayan: Jurnal Jurusan Pendidikan Bahasa Arab, 10(2), 121. https://doi.org/10.24042/albayan.v10i2.2996

Hylton, M. E. (2018). The role of civic literacy and social empathy on rates of civic engagement among university students. Journal of Higher Education Outreach and Engagement, 22(1), 87-106. 
Izzaty, R. E., Suardiman, S. P., Ayriza, Y., Purwandari, Heriyanto, \& Kusmaryani, R. E. (2013). Perkembangan Peserta Didik. UNY Press.

Kasmaienezhadfard, S., Pourrajab, M., \& Rabbani, M. (2015). Effects of pictures in textbooks on students' creativity. Multi Disciplinary Edu Global Quest, 2(14), 8396.

Liu, E. Z. F., \& Chen, P.-K. (2013). The effect of game-based learning on students' learning performance in science learning -a case of "conveyance go." Procedia Social and Behavioral Sciences, 103, 1044-1051. https://doi.org/10.1016/j.sbspro.2013.10.430

Mardati, A., \& Wangid, M. N. (2015). Pengembangan media permainan kartu gambar dengan teknik make a match untuk kelas I SD. Jurnal Prima Edukasia, 3(2), 120. https://doi.org/10.21831/jpe.v3i2.6532

Morgan, L. (2016). Developing civic literacy and efficacy: insights gleaned through the implementation of project citizen. I.E.: Inquiry in Education, 8(1), 3.

Mostowfi, S., Mamaghani, N. K., \& Khorramar, M. (2016). Designing playful learning by using educational board game for children in the age range of $7-12$ : (a case study: recycling and waste separation education board game). International Journal of Environmental \& Science Education, 11(12), 5453-5476.

Padang, M. N. B., Angin, R. B. P., \& Saragi, D. (2018). The effect of index card match method and learning motivation toward student 's learning outcomes in elementary school. Journal of Research \& Method in Education, 8(1), 69-78. https://doi.org/10.9790/7388-0801016978

Phuntsho, U. (2018). The impact of motivation on student 's academic achievement and learning outcomes in mathematics - An action research. Journal of Educational Action Research (JEAR), 1(3), 41-55. https://doi.org/10.13140/RG.2.2.22064.46084/1

Raharjo, Armawi, A., \& Soerjo, D. (2017). Penguatan civic literacy dalam pembentukan warga negara yang baik (good citizen ) dan implikasinya terhadap ketahanan pribadi warga negara muda. Jurnal Ketahanan Nasional, 23(2), 175198.

Rahman, I. N. (2016). Pengaruh civic literacy dalam pembelajaran pendidikan kewarganegaraan terhadap partisipasi politik siswa: Studi deskriptif analitis terhadap siswa SMA kota Bandung. Untirta Civic Educatioan Journal, 1(1), 6884.

Rumidjan, R., Sumanto, S., \& Badawi, A. (2017). Pengembangan media kartu kata untuk melatih keterampilan membaca permulaan pada siswa kelas I SD. Sekolah Dasar: Kajian Teori Dan Praktik Pendidikan, 26(1), 62-68. https://doi.org/10.17977/um009v26i12017p062

Sahrin, V., \& Hasan, M. (2019). Increasing students' vocabulary acquisition by master and mastery cards game. JOALL (Journal of Applied Linguistics \& Literature), 4(1), 69-76. https://doi.org/10.33369/joall.v4i1.6342

Saunders, D., Percival, F., \& Vartiainen, M. (1996). The Simulation and Gaming 
Yearbook. Kogan Page Limited.

Scalise, N. R., Daubert, E. N., \& Ramani, G. B. (2020). Benefits of playing numerical card games on head start children's mathematical skills. Journal of Experimental Education, 88(2), 200-220. https://doi.org/10.1080/00220973.2019.1581721

Selvi, M., \& Çoşan, A. Ö. (2018). The effect of using educational games in teaching kingdoms of living things. Universal Journal of Educational Research, 6(9), 20192028. https://doi.org/10.13189/ujer.2018.060921

Shabiralyani, G., Hasan, K. S., Hamad, N., \& Iqbal, N. (2015). Impact of Visual Aids in Enhancing the Learning Process Case Research: District Dera Ghazi Khan. Journal of Education and Practice, 6(19), 226-233.

Su, T. F., Cheng, M. T., \& Lin, S. H. (2014). Investigating the effectiveness of an educational card game for learning how human immunology is regulated. $C B E$ Life Sciences Education, 13(3), 504-515. https://doi.org/10.1187/cbe.13-10-0197

Verhallen, M. J. A. J., \& Bus, A. G. (2011). Young second language learners' visual attention to illustrations in storybooks. Journal of Early Childhood Literacy, 11(4), 480-500. https://doi.org/10.1177/1468798411416785

Yang, C.-H., Cheng, J.-C., \& Chou, M.-J. (2016). Empowering Children's Creativity with The Instruction of Wordless Picture Books. European Journal of Research and Reflection in Educational Sciences, 4(7), 1-16. 